\title{
EFFECTS OF HYDROPHILIC POLYMERS ON SOIL WATER, WHEAT PLANT AND MICROORGANISMS
}

\author{
KHODADADI DEHKORDI, D. \\ Department of Water Engineering and Sciences, Ahvaz Branch, \\ Islamic Azad University, Ahvaz, Iran \\ e-mail:davood_kh70@yahoo.com; dkhodadadi@iauahvaz.ac.ir; phone: +989163033474 \\ (Received $5^{\text {th }}$ Nov 2017; accepted $12^{\text {th }}$ Feb 2018)
}

\begin{abstract}
In this study, two types of superabsorbent polymers, Super-AB-A-200 (A-200) and Super-ABA-300 (A-300), at $180 \mathrm{~kg} \mathrm{ha}^{-1}$ were applied by scattering and mass treatments in an experimental farm to assess their influences on spring wheat growth (Chamran variety) and on the physical characteristics and microbial plenty of soil in Shush region, Iran. The following treatments were used in this study: the control treatment (CT, without SAPs), A-200 with mass application (A-200-M), A-300 with mass application (A-300-M), A-200 with scattered application (A-200-S), and A-300 with scattered application (A-300-S). Approximately $0.3 \mathrm{~m}^{3}$ of irrigation water was supplied for every subplot. The results indicated that superabsorbent polymers significantly enhanced the soil water content in the three growth stages compared with the control. The use of superabsorbent polymers did not have obvious opposite influences on the soil microbial colony and might even increase soil microbial movement.

Keywords: soil hygroscopic moisture, superabsorbent polymer, soil water content, wheat plant, waterholding capacity

Abbreviations: AW: Available water-holding; CT: Control treatment; CEC: Cation exchange capacity; DOC: Dissolved organic carbon; MBC: Microbial biomass carbon; OMC: Organic matter carbon; A-200: Super-AB-A-200; A-300: Super-AB-A-300; SAP: Superabsorbent polymer; SWSA: Soil water-stable aggregates; SHM: Soil hygroscopic moisture; SMR: Soil microbic respiration; SWC: Soil water content; WC: Water-holding capacity; WSA: Water-stable aggregates; RG: 16S rRNA gene
\end{abstract}

\section{Introduction}

Numerous countries worldwide do not have enough water resources to meet their actual environmental, urban, and agricultural requirements (Bouwer, 2002). Iran receives a nonuniform distribution of rainfall every year and has limited water resources. Therefore, it is a dry country, and it always faces water shortage problems. A new technique for managing soil water is to use superabsorbent polymer (SAP) as a water reservoir for preventing water loss and increasing irrigation efficiency (Seyed Doraji et al., 2010). SAP acts as a soil reformer and decreases soil water loss and increases crop yield. SAP can take up large amounts of water and aquatic solutions and increase the soil water-holding capacity (WC) (Khadem et al., 2010). SAP has a positive impact on water and nutrient retention in the soil. It postpones the time required to reach a permanent wilting point and prolongs plant survival under water stress conditions (Orikiriza et al., 2009). Yang et al. (2014) showed that adding a hydrophilic polymer to soil led to a significant increase in soil WC compared to controls. Yadollahi et al. (2012) showed that Super-AB-A-200 and organic matters could increase soil water retention significantly. Khodadadi Dehkordi (2017) reported that Super-AB-A-200 polymer could store water and nutrients in the sandy soil and release them under drought stress conditions. Besides, it could improve sandy soils and increase water-holding capacity. Previous studies on superabsorbent polymers have investigated their influences on the chemical and physical characteristics of soil 
(Zhang and Miller, 1996); however, few have assessed the effects of hydrophilic polymers on microorganisms in soil and moisture available to plants under natural conditions. This study aimed to evaluate variations in the physical properties and microbial movement of soil after applying superabsorbent polymers in the field during the growth of the Chamran wheat variety.

\section{Materials and methods}

\section{Experimental farm and treatments}

The farm experiments were performed in Shush, Khuzestan province, Iran. This region has a semiarid climate and mean annual precipitation of $213 \mathrm{~mm}$ (Table 1). The soil texture was sandy loam. It had an organic matter carbon (OMC) of $0.5 \%, \mathrm{pH}$ of 7 , and cation exchange capacity (CEC) of $11.8 \mathrm{cmol} \mathrm{kg}$; it was classified as Alfisols in the USA soil taxonomy. The experimental farm was divided into five plots. One plot was determined as the control treatment (CT) (without SAPs), and various hydrophilic polymer treatments were randomly applied in the other plots. For creating replicates, each plot $(4 \mathrm{~m} \times 4 \mathrm{~m})$ was divided into six equal subplots. Therefore, 30 subplots were evaluated in total. Chamran wheat variety that was native to and a special variety from Shush was used for cultivation in three growing seasons. Chamran is an early-ripening and spring variety of wheat (Triticum aestivum L.). The hydrophilic polymers used in this study were Super-AB-A-200 (A-200) and Super-AB-A-300 (A-300) (Tables 2 and 3) (both manufactured by Rahab Resin Co., product license held by Iran Polymer and Petrochemical Institute) (Rahab Resin Co, 2016). These hydrophilic polymers are granular, and they are a tripolymer of acrylamide, acrylic acid, and acrylate potassium. These polymers are inexpensive, and they are easier to obtain than other types of hydrophilic polymers in Iran. The following treatments were used in this study: the control treatment (CT, without SAPs), A-200 with mass application (A-200M), A-300 with mass application (A-300-M), A-200 with scattered application (A-200S), and A-300 with scattered application (A-300-S). The experimental design is indicated in Figure 1. Approximately $0.3 \mathrm{~m}^{3}$ of irrigation water was supplied for every subplot; this is similar to the regional irrigation strategy. The irrigation water for the CT was pure and did not contain a superabsorbent. For mass application in every subplot, a depth of $1.5 \mathrm{~cm}$ from the soil surface was gathered and blended with hydrophilic polymers and distributed equally at a superabsorbent polymer density of $180 \mathrm{~kg} \mathrm{ha}^{-1}$. Next, $0.3 \mathrm{~m}^{3}$ of irrigation water was supplied for each subplot. For scattered application in every subplot, $0.3 \mathrm{~m}^{3}$ of irrigation water and a blend of hydrophilic polymers was sprayed onto the soil surface. The wheat variety was planted on November 22, 20132014-2015. Hydrophilic polymers were applied to the soil on December 27, 2013-20142015, when the crops became strong enough and started to grow. Soil samples were gathered at three crucial stages: stem elongation stage (sampled on January 1, 20142015-2016), heading stage (February 27, 2014-2015-2016), and dough stage (March 25, 2014-2015-2016). By using a core sampler, the soil samples were gathered at a depth of 0-12 cm and a space of 1-6 cm from the wheat plants. Six subsamples from each subplot were blended to prepare a compound sample. For analyzing the soil water-stable aggregates (SWSA) and other physical (maintained at $2{ }^{\circ} \mathrm{C}$ ) and microbial (maintained at $-24^{\circ} \mathrm{C}$ ) characteristics of soil, the samples were passed through 8 and $2 \mathrm{~mm}$ screens, respectively. After harvesting, the plant shoot length in the three phases and the dry weight of wheat grains were determined. 


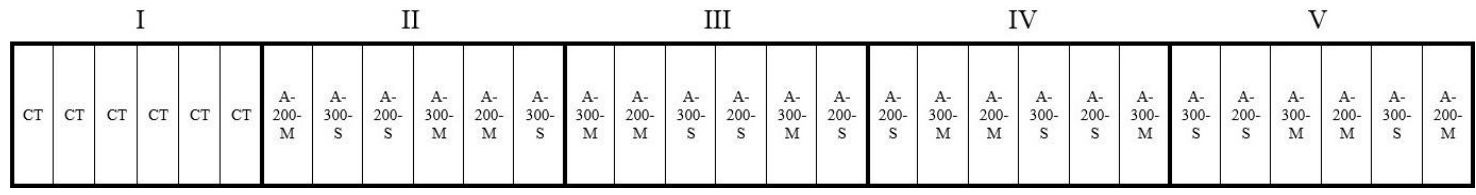

Figure 1. The experimental design of this study

Table 1. Some weather parameters of Shush city

\begin{tabular}{c|c|c|c|c|c|c|c}
\hline Month & $\begin{array}{c}\text { Average of } \\
\text { min } \\
\text { temperature } \\
\left({ }^{\circ} \mathbf{C}\right)\end{array}$ & $\begin{array}{c}\text { Average of } \\
\text { max } \\
\text { temperature } \\
\left({ }^{\circ} \mathbf{C}\right)\end{array}$ & $\begin{array}{c}\text { Average of } \\
\text { temperature } \\
\left({ }^{\circ} \mathbf{C}\right)\end{array}$ & $\begin{array}{c}\text { Average of } \\
\text { min } \\
\text { humidity } \\
(\boldsymbol{\%})\end{array}$ & $\begin{array}{c}\text { Average of } \\
\text { max } \\
\text { humidity } \\
(\boldsymbol{\%})\end{array}$ & $\begin{array}{c}\text { Sum of } \\
\text { rainfall } \\
(\mathbf{m m})\end{array}$ & $\begin{array}{c}\text { Sum of } \\
\text { sunshine } \\
\text { hours }\end{array}$ \\
\hline October & 20.0 & 40.2 & 29.8 & 17.7 & 58.3 & 0 & 287.60 \\
November & 14.4 & 29.3 & 20.3 & 37.1 & 75.7 & 25.8 & 178.60 \\
December & 5.2 & 21.9 & 13.1 & 35.5 & 81.2 & 0 & 260.36 \\
January & 6.4 & 21.8 & 13.4 & 43.6 & 83.5 & 12.5 & 178.60 \\
February & 6.1 & 20.9 & 13.1 & 40.4 & 78.2 & 28.4 & 174.27 \\
March & 9.0 & 24.3 & 16.0 & 30.3 & 70.1 & 29 & 210.10 \\
April & 15.3 & 32.4 & 23.2 & 33.1 & 80.0 & 5.5 & 215.07 \\
May & 21.7 & 40.9 & 29.9 & 28.7 & 65.0 & 2.5 & 246.78 \\
June & 24.8 & 46.3 & 35.0 & 19.0 & 49.0 & 0 & 300.38 \\
July & 26.6 & 48.1 & 36.7 & 20.6 & 52.6 & 0 & 356.47 \\
August & 27.4 & 49.7 & 38.0 & 21.5 & 54.8 & 0 & 352.20 \\
September & 23.3 & 45.5 & 33.7 & 24.3 & 68.1 & 0 & 332.60 \\
\hline
\end{tabular}

Table 2. The characteristics of Super-AB-A-200 polymer

\begin{tabular}{c|c}
\hline Characteristics & Super-AB-A-200 polymer \\
\hline Shape & granular \\
Density & $1.4-1.5\left(\mathrm{gr} . \mathrm{cm}^{-3}\right)$ \\
Size of particles & $50-150(\mu \mathrm{m})$ \\
Maximum stability in soil & $7(\mathrm{year})$ \\
Practical capacity of water uptake & $220\left(\mathrm{~g} . \mathrm{g}^{-1}\right)$ \\
\hline
\end{tabular}

Table 3. The characteristics of Super-AB-A-300 polymer

\begin{tabular}{c|c}
\hline Characteristics & Super-AB-A-300 polymer \\
\hline Shape & granular \\
Density & $1.4-1.5\left(\mathrm{gr} . \mathrm{cm}^{-3}\right)$ \\
Size of particles & $30-100(\mu \mathrm{m})$ \\
Maximum stability in soil & $5(\mathrm{year})$ \\
Practical capacity of water uptake & $600\left(\mathrm{~g} \cdot \mathrm{g}^{-1}\right)$ \\
\hline
\end{tabular}

\section{Determination of SWSA}

Soil aggregates of various sizes $(<0.25,0.25-0.5,0.5-1,1-2,2-5$, and $>5 \mathrm{~mm})$ were separated using the wet sifting procedure according to the Elliot method (Elliot, 1986; 
Li et al., 2014). At room temperature and before the start of sifting, a $105 \mathrm{~g}$ sample was immersed into water on the largest sieve $(2 \mathrm{~mm})$ for $6 \mathrm{~min}$. In a sedimentation cylinder and under water, the soils were sifted by mildly moving the screen vertically through water 60 times in $2.5 \mathrm{~min}$. In all cases, the improvements from wet sifting were $>99 \%$ by weight. The sum portion of the fraction weights was used for explaining the weight of every SWSA.

\section{Evaluation of soil available water-holding $(A W)$ and soil hygroscopic moisture (SHM)}

First, a $30 \mathrm{~mL}$ beaker including $15 \mathrm{~g}$ of desiccated soil was placed in a dryer, and its bottom was saturated with $\mathrm{K}_{2} \mathrm{SO}_{4}$ solution. The dryer temperature was kept constant at $20^{\circ} \mathrm{C}$. After water uptake for 7 days, the beaker was removed, weighed, and returned to the dryer. This process was repeated many times until the beaker weight with soil became stable. Then, the beaker (including the soil sample) was placed in an oven at $105^{\circ} \mathrm{C}$ for 1 day. The water content process was used to measure the SHM. The AW can be evaluated for the plant by using the SHM and soil water content (SWC) by Equation 1 (Li et al., 2014; Gupta and Larson, 1979):

$$
\mathrm{AW}=\mathrm{SWC}-[2 \times \mathrm{SHM}]
$$

\section{Evaluation of soil DNA extraction and real-time PCR of bacterial plenty}

Nucleic acids were obtained from $0.6 \mathrm{~g}$ of soil using a MoBio UltraClean ${ }^{\mathrm{TM}}$ soil DNA isolation kit according to the manufacture's instruction with a slight adjustment (He et al., 2007). The DNA obtained was saved at $-24^{\circ} \mathrm{C}$ before usage. The bacterial plenty was assessed using the real-time PCR procedure with a focus on the 16S rRNA gene (RG) in an iCycler iQ5 thermocycler (He et al., 2007). Real-time PCR was performed using a $25 \mu \mathrm{L}$ reaction volume including $12.5 \mu \mathrm{L}$ of $2 \times$ Premix Ex Taq, 100 $\mathrm{nM}$ of each primer, $120 \mathrm{nM}$ of the probe, and $1 \mu \mathrm{L}$ of the tenfold-diluted DNA template (1-10 ng) ( $\mathrm{Li}$ et al., 2014). The elaboration conditions were as follows: $97^{\circ} \mathrm{C}$ for $12 \mathrm{~s}$, 40 cycles at $97^{\circ} \mathrm{C}$ for $17 \mathrm{~s}$, and $60 \mathrm{~s}$ at $58^{\circ} \mathrm{C}$.

\section{Analysis of soil microbial biomass carbon (MBC)}

The chloroform fumigation extraction procedure was used for measuring the soil microbic biomass (Vance et al., 1987). In this method, each fresh soil sample was divided into 10 parts. Five of these parts (each including $15 \mathrm{~g}$ of dried soil) were placed into $100 \mathrm{~mL}$ bottles, and chloroform fumigation was carried out with adding of ethanolfree chloroform ( $15 \mu \mathrm{Lg}^{-1}$ of dried soil). Then, the soils were blended completely inside the bottle. The soils were fumigated excessively with chloroform for 1 day at $35^{\circ} \mathrm{C}$ in dryers. When fumigant of the soils were removed, they were extracted with $45 \mathrm{~mL}$ of $0.5 \mathrm{M} \mathrm{K}_{2} \mathrm{SO}_{4}$ for $35 \mathrm{~min}$. The other five nonfumigated soils were obtained similarly at the start of fumigation. The $\mathrm{MBC}$ was assessed as the difference in $\mathrm{K}_{2} \mathrm{SO}_{4}$-extractable dissolved organic carbon (DOC) between the fumigated and nonfumigated soils using the following extractability correction factor: $K_{C}=0.5$ for DOC (Li et al., 2014; Jonasson et al., 1996; Rinnan et al., 2008). Then, the extracted DOC was measured using a total DOC analyzer. 


\section{Measurement of soil microbial respiration (SMR)}

The soil respiration was determined using the procedure explained by Chen et al. (2000). Fresh soil (equivalent to $25 \mathrm{~g}$ dry weight) was placed in a sealed $500 \mathrm{~mL}$ bottle and settled at $20^{\circ} \mathrm{C}$ for 1 day. The $\mathrm{CO}_{2}$ arising from the soil was captured in $0.2 \mathrm{M}$ $\mathrm{NaOH}$ and assessed by titration with $0.2 \mathrm{M} \mathrm{HCl}$ to the phenolphthalein end point after adding $2 \mathrm{M} \mathrm{BaCl}_{2}$. Several controls (i.e., soil-free bottle) were exposed to the same situation and applied as blanks. The derived $\mathrm{CO}_{2}$ value was measured from the difference in molarity between $\mathrm{NaOH}$ from the samples and blanks.

\section{Data analysis}

The data analysis was carried out with using SPSS 21.0 software. Analysis of variance (ANOVA) was used to check the differences among the treatments used. $\mathrm{P}<0.05$ was considered statistically significant.

\section{Results}

\section{Plant characteristics}

Spring wheat plants grew rapidly from the stem elongation to the heading stage and quickly from the heading to the dough stage. The plant shoot lengths indicated significant differences among the three phases; however, the influence of hydrophilic polymers was minimal (Fig. 2). Only A-300-M significantly enhanced the total dry weight of wheat grain $(\mathrm{P}<0.05)$ (Fig. 3).

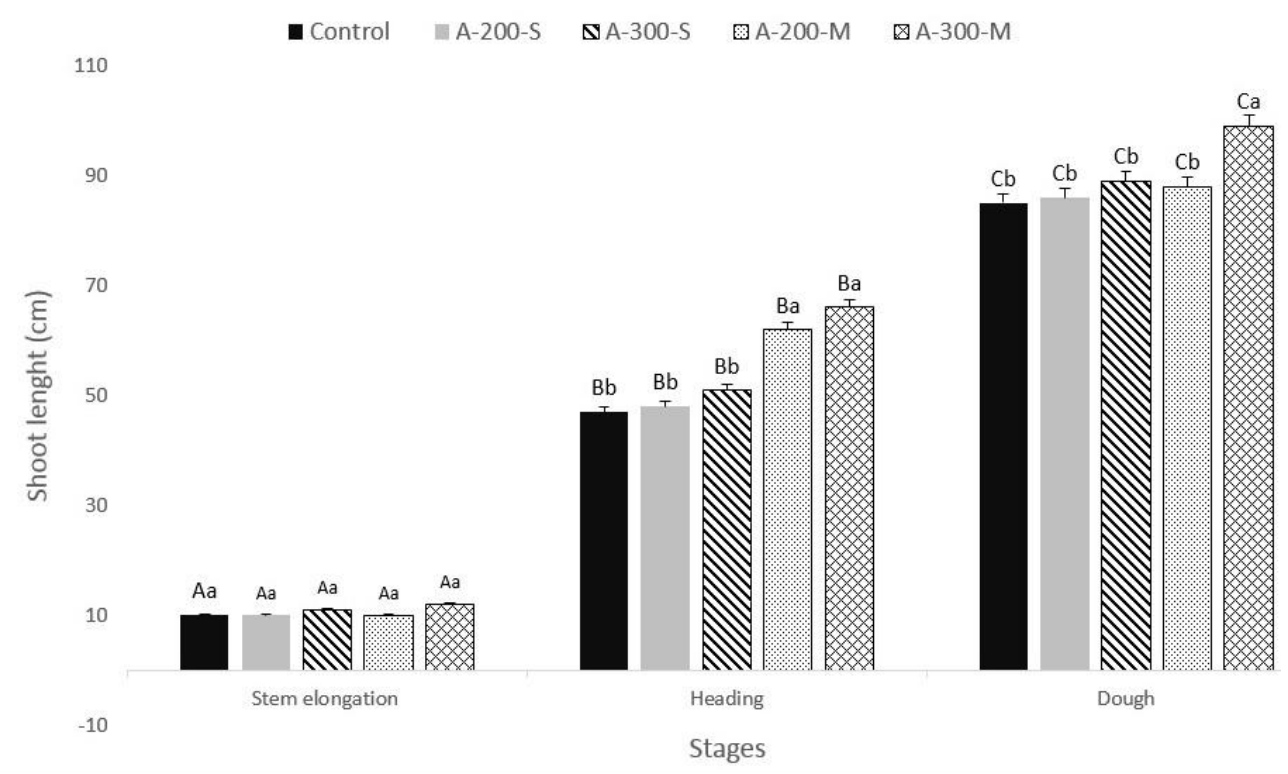

Figure 2. The shoot length of Chamran variety plants in varied stages and under varied hydrophilic polymer treatments. Varied capital letters indicate significant differences between stages for the same SAP treatment $(P<0.05)$. Varied lowercase letters indicate significant differences between hydrophilic polymer treatments in the same wheat growth stage $(P<0.05)$. Bars show the standard errors 


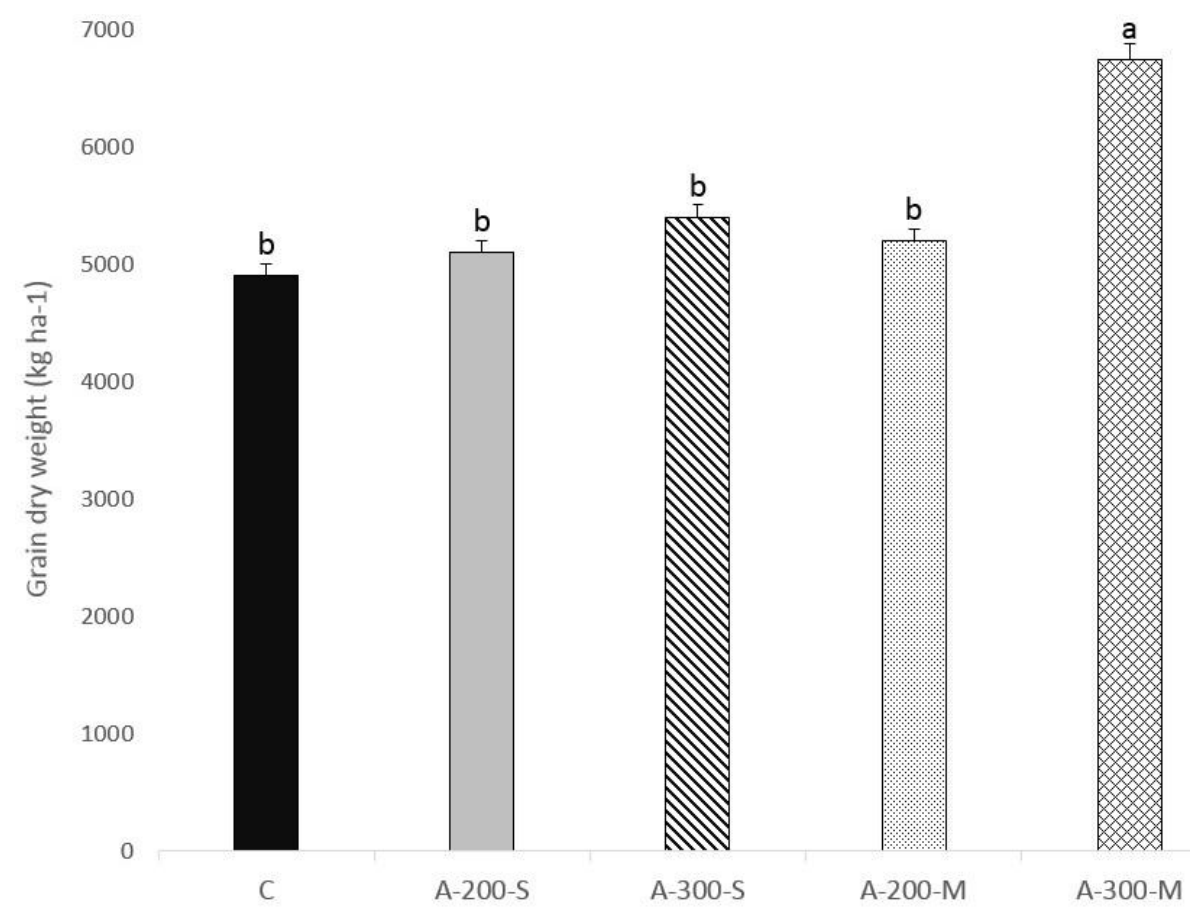

Figure 3. The grain dry weight of Chamran variety plants in varied stages and under varied hydrophilic polymer treatments. Bars show the standard errors. Bars with varied letters show significant differences at $p<0.05$

\section{SWSA}

Table 4 shows the variation of SWSA over all Chamran variety growths and between treatments. The soil particle sizes showed significant differences among the three phases $(\mathrm{P}<0.05)$. SAP application significantly enhanced the macro soil aggregates (size $>0.25 \mathrm{~mm}$ ) compared with CTs in the heading and dough phases, whereas the differences among the two hydrophilic polymer treatments were not significant.

\section{$A W, S H M$, and $S W C$}

SWC varied by hydrophilic polymer treatment and growth stage (Fig. 4), whereas SHM only varied by hydrophilic polymer treatment (Fig. 5). In the stem elongation, heading, and dough stages, all superabsorbent treatments significantly enhanced SWC compared with CTs $(\mathrm{P}<0.05)$. Furthermore, there were significant differences in SWC between the superabsorbent treatments, particularly in the heading and dough stages. The influences of mass treatments were greater than those of scattering treatments. Similarly, in the three phases, all superabsorbent treatments significantly enhanced SHM compared with CTs $(\mathrm{P}<0.05)$. However, differences were not seen in SHM when using hydrophilic polymers. Figure 6 reveals the clear influences on AW in the first two Chamran variety growth phases and between the hydrophilic polymer treatments. The amounts of AW in the dough phase were negative; therefore, soil water could not be used completely by wheat plants in this phase. This decrease in AW during Chamran variety growth was very identical to that seen in SWC. Furthermore, the mass treatments of hydrophilic polymers were more efficient in water holding than scattering treatments. 
Table 4. Water-stable soil aggregate composition at different stages and under different treatments

\begin{tabular}{|c|c|c|c|c|c|c|}
\hline \multirow{2}{*}{ Application method } & \multicolumn{6}{|c|}{ SWSA content $(\%)$} \\
\hline & $<0.25 \mathrm{~mm}$ & $0.25-0.5 \mathrm{~mm}$ & $0.5-1 \mathrm{~mm}$ & 1-2 mm & $2-5 \mathrm{~mm}$ & $>5 \mathrm{~mm}$ \\
\hline \multicolumn{7}{|l|}{ Stem elongation stage } \\
\hline $\mathrm{C}$ & $52.0 \mathrm{Aa}$ & 17.1 Aa & $11.2 \mathrm{Aa}$ & $8.5 \mathrm{Aa}$ & $9.1 \mathrm{Aa}$ & $9.7 \mathrm{Aa}$ \\
\hline A-200-S & 45.2 Aa & $18.3 \mathrm{Ba}$ & $12.5 \mathrm{Ba}$ & $9.4 \mathrm{Ba}$ & $10.4 \mathrm{Ba}$ & $11.3 \mathrm{Ba}$ \\
\hline A-300-S & 47.3 Aa & $18.2 \mathrm{Ba}$ & $12.2 \mathrm{Ba}$ & $9.6 \mathrm{Ba}$ & $10.6 \mathrm{Ba}$ & $11.6 \mathrm{Ba}$ \\
\hline A-200-M & 45.8 Аa & $18.1 \mathrm{Ba}$ & $12.3 \mathrm{Ba}$ & $9.3 \mathrm{Ba}$ & $10.2 \mathrm{Ba}$ & $11.3 \mathrm{Ba}$ \\
\hline A-300-M & $49.7 \mathrm{Aa}$ & $19.4 \mathrm{Ba}$ & $12.8 \mathrm{Ba}$ & $10.1 \mathrm{Ba}$ & $11.2 \mathrm{Ba}$ & $12.4 \mathrm{Ba}$ \\
\hline \multicolumn{7}{|l|}{ Heading stage } \\
\hline $\mathrm{C}$ & $51.2 \mathrm{Aa}$ & 17.2 Ab & $11.5 \mathrm{Ab}$ & $8.4 \mathrm{Ab}$ & $9.5 \mathrm{Ab}$ & $9.8 \mathrm{Ab}$ \\
\hline A-200-S & $34.2 \mathrm{Bb}$ & $22.3 \mathrm{Aa}$ & $21.3 \mathrm{Aa}$ & $12.5 \mathrm{Aa}$ & $13.6 \mathrm{Aa}$ & 14.4 Aa \\
\hline A-300-S & $35.3 \mathrm{Bb}$ & $23.5 \mathrm{Aa}$ & $22.6 \mathrm{Aa}$ & $12.7 \mathrm{Aa}$ & $13.7 \mathrm{Aa}$ & 14.6 Aa \\
\hline A-200-M & $35.6 \mathrm{Bb}$ & $22.1 \mathrm{Aa}$ & $21.2 \mathrm{Aa}$ & $12.3 \mathrm{Aa}$ & $13.5 \mathrm{Aa}$ & 14.1 Aa \\
\hline A-300-M & $37.4 \mathrm{Bb}$ & $24.6 \mathrm{Aa}$ & 23.6 Aa & 13.5 Aa & 14.4 Aa & $15.3 \mathrm{Aa}$ \\
\hline \multicolumn{7}{|l|}{ Dough stage } \\
\hline $\mathrm{C}$ & $50.6 \mathrm{Aa}$ & 17.4 Ab & $11.7 \mathrm{Ab}$ & $8.3 \mathrm{Ab}$ & $9.8 \mathrm{Ab}$ & $9.9 \mathrm{Ab}$ \\
\hline A-200-S & $32.4 \mathrm{Bb}$ & $22.6 \mathrm{Aa}$ & $21.4 \mathrm{Aa}$ & $12.6 \mathrm{Aa}$ & $13.5 \mathrm{Aa}$ & 14.3 Aa \\
\hline A-300-S & $33.5 \mathrm{Bb}$ & $23.7 \mathrm{Aa}$ & $22.7 \mathrm{Aa}$ & $12.8 \mathrm{Aa}$ & 13.7 Aa & $14.6 \mathrm{Aa}$ \\
\hline A-200-M & $33.4 \mathrm{Bb}$ & $22.3 \mathrm{Aa}$ & $21.4 \mathrm{Aa}$ & $12.5 \mathrm{Aa}$ & $13.4 \mathrm{Aa}$ & 14.2 Aa \\
\hline A-300-M & $35.6 \mathrm{Bb}$ & $24.8 \mathrm{Aa}$ & $23.8 \mathrm{Aa}$ & 13.6 Aa & 14.5 Aa & $15.4 \mathrm{Aa}$ \\
\hline
\end{tabular}

Different capital letters indicate significant differences between different stages for the same hydrophilic polymer treatment $(\mathrm{P}<0.05)$. Varied lowercase letters indicate significant differences between different hydrophilic polymer treatments in the same growth stage $(\mathrm{P}<0.05)$

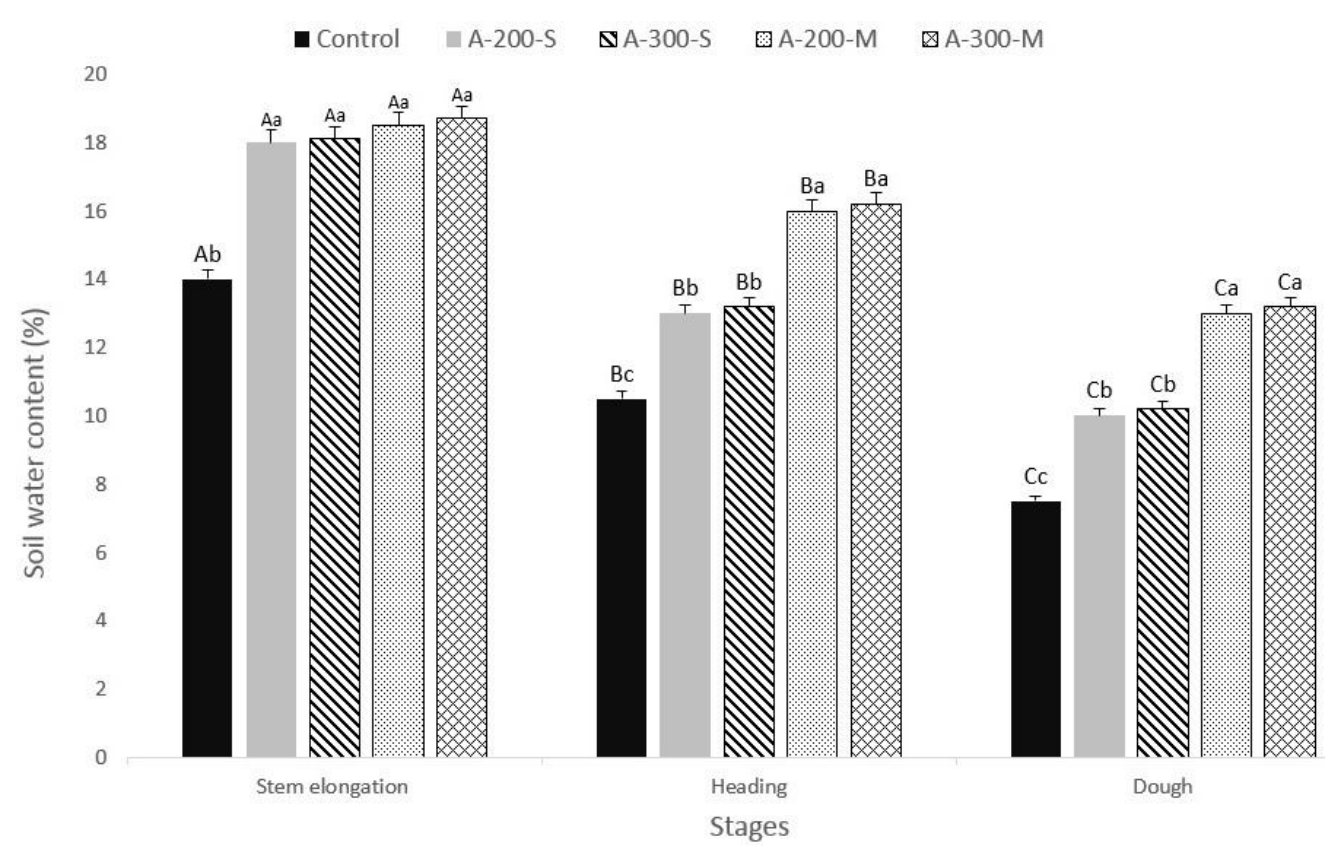

Figure 4. Soil water content (SWC) in varied stages and under varied hydrophilic polymer treatments. Different capital letters indicate significant differences between stages for the same SAP treatment $(P<0.05)$. Varied lowercase letters indicate significant differences between hydrophilic polymer treatments in the same wheat growth stage $(P<0.05)$. Bars show the standard errors 


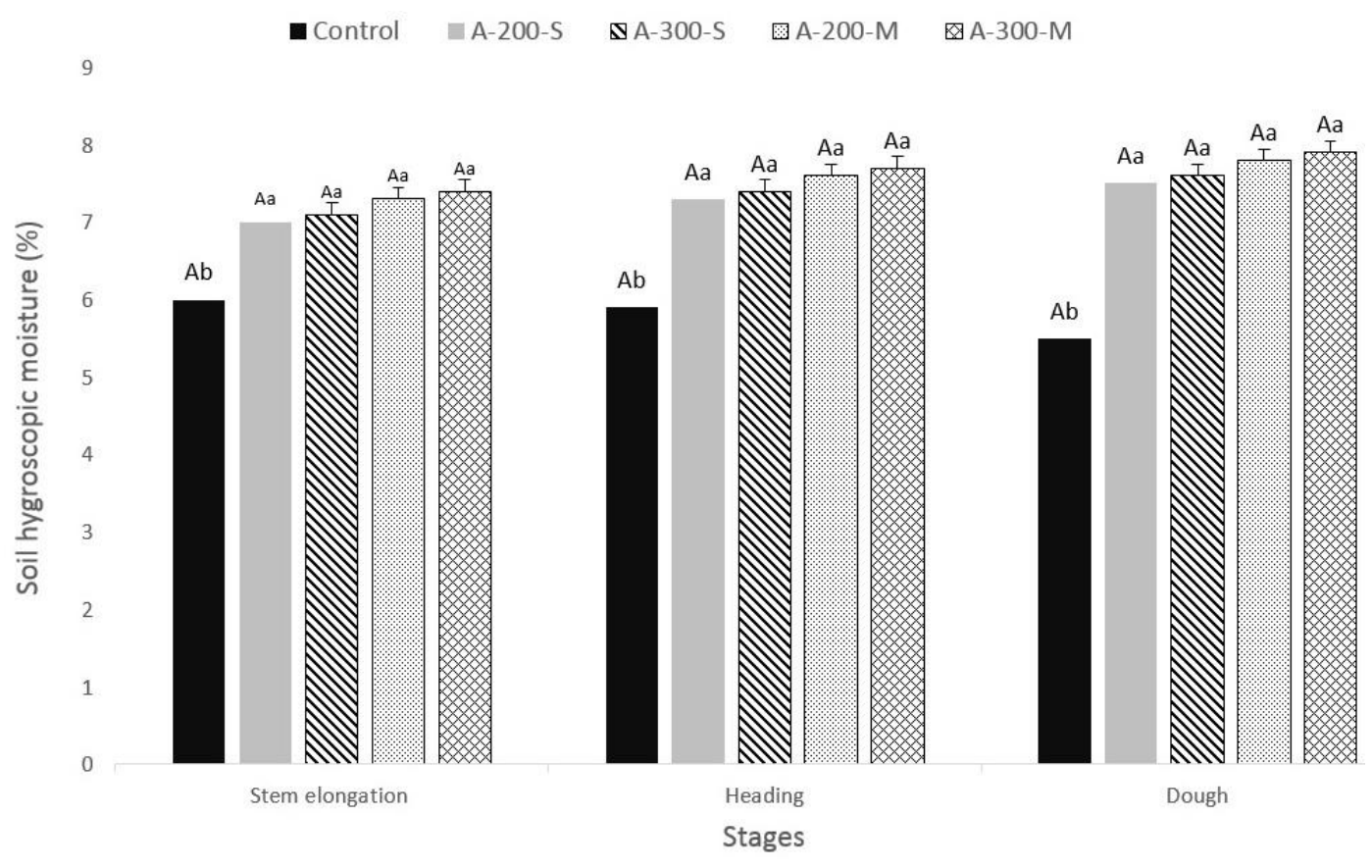

Figure 5. Soil hygroscopic moisture (SHM) in varied stages and under varied hydrophilic polymer treatments. Different capital letters indicate significant differences between stages for the same SAP treatment $(P<0.05)$. Varied lowercase letters indicate significant differences between hydrophilic polymer treatments in the same wheat growth stage $(P<0.05)$. Bars show the standard errors

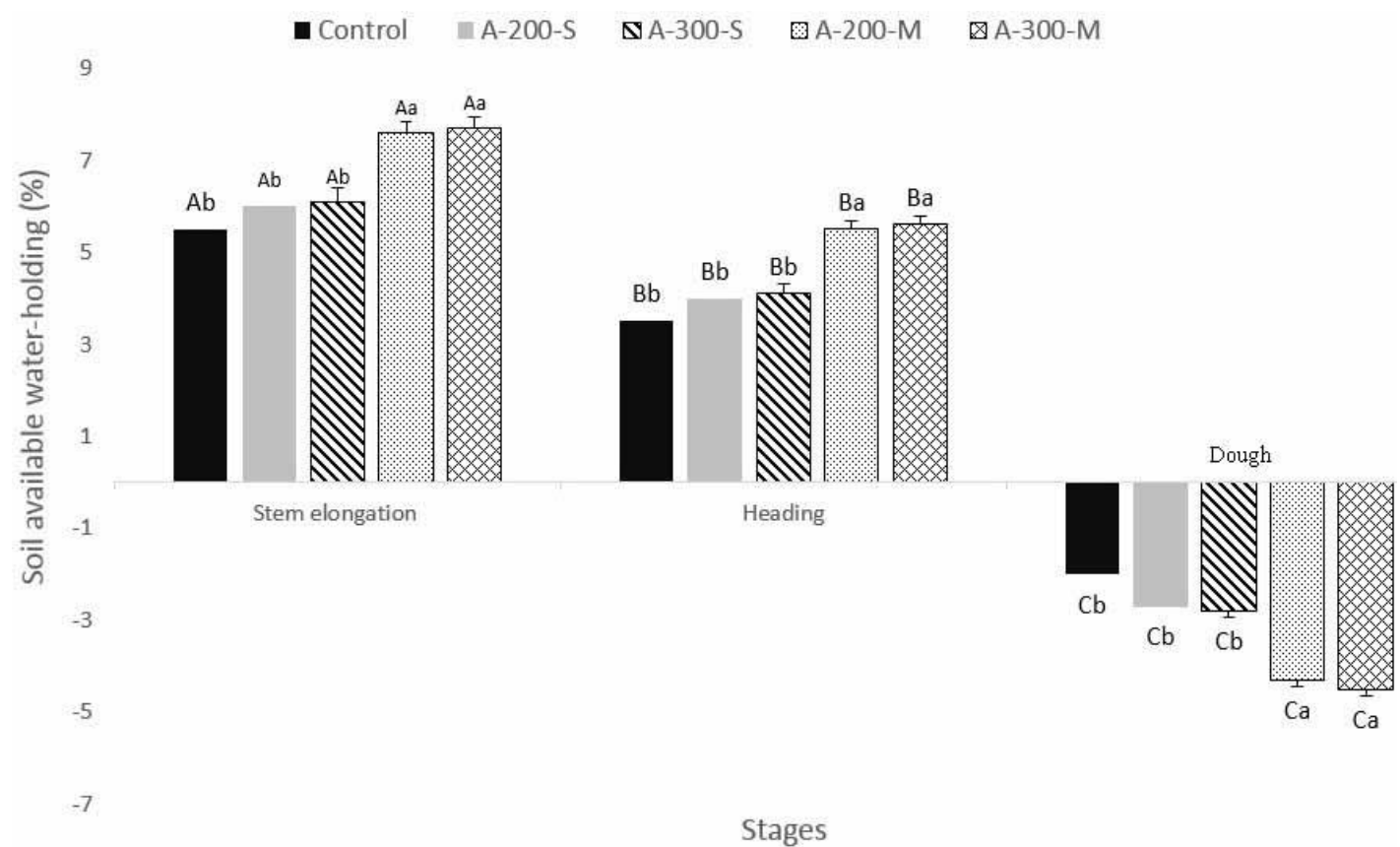

Figure 6. Soil available water-holding $(A W)$ in varied stages and under varied hydrophilic polymer treatments. Different capital letters indicate significant differences between stages for the same SAP treatment $(P<0.05)$. Varied lowercase letters indicate significant differences between hydrophilic polymer treatments in the same wheat growth stage $(P<0.05)$. Bars show the standard errors 


\section{Bacterial plenty in soil}

The bacterial plenty, measured by the number of RG copies per gram of desiccated soil, differed between the Chamran variety growth phases and hydrophilic polymer treatments (Fig. 7). In the stem elongation stage, the mass treatments significantly enhanced the bacterial RG copy numbers compared with scattering treatment and CTs. In both the heading and the dough stages, the bacterial RG copy numbers in all hydrophilic polymer treatments were significantly greater than those in the two CTs, respectively (Fig. 7). Throughout the three growth phases, the highest number of bacterial RG copies were seen in the heading phase in all treatments $(\mathrm{P}<0.05)$.

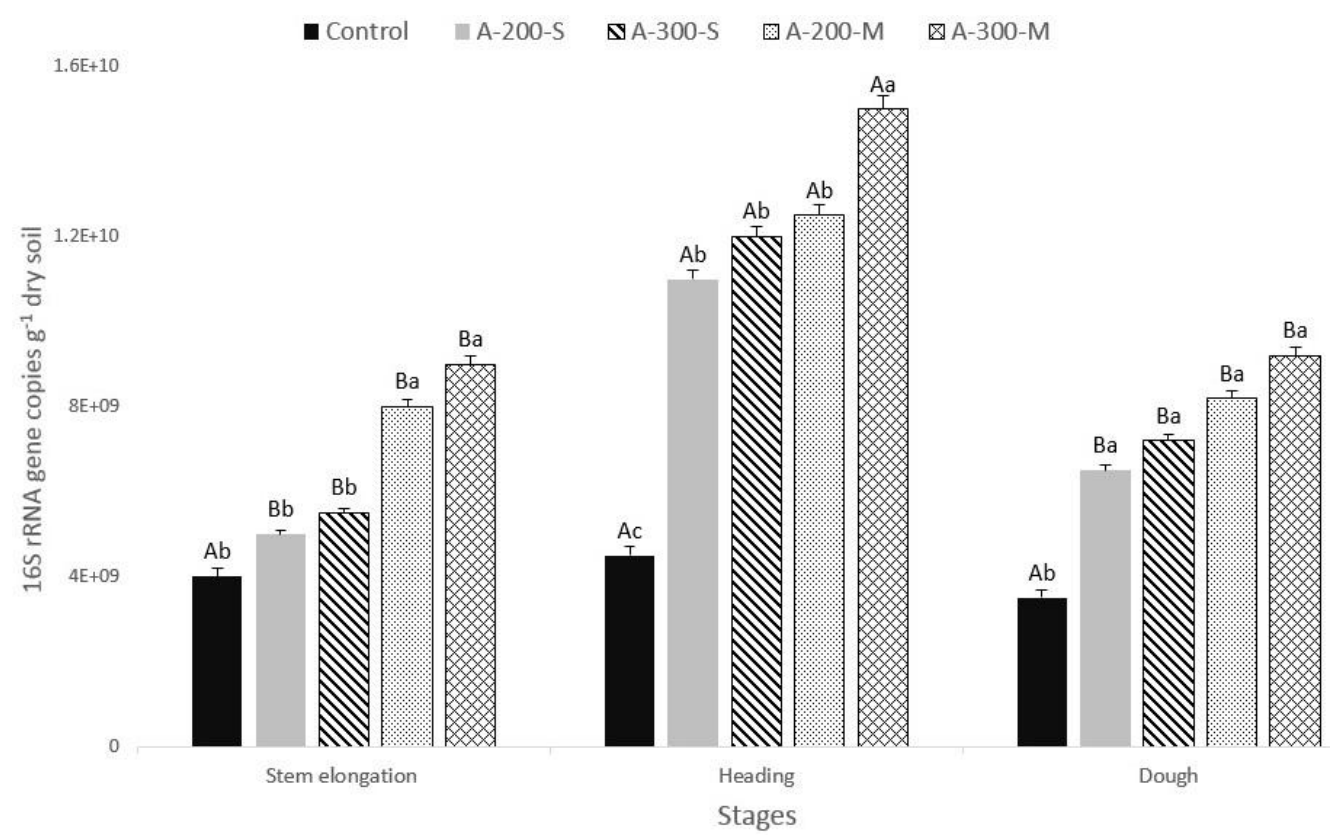

Figure 7. Abundance of bacteria in varied stages and under varied hydrophilic polymer treatments. Different capital letters indicate significant differences between stages for the same SAP treatment $(P<0.05)$. Varied lowercase letters indicate significant differences between hydrophilic polymer treatments in the same wheat growth stage $(P<0.05)$. Bars show the standard errors

\section{SMR and Soil MBC}

There were significant differences in microbial movement between the different phases (P < 0.05) (Figs. 8 and 9). Microbial movement, defined by SMR and MBC, was the greatest in the heading stage, indicating a trend comparable to that of bacterial plenty. Meanwhile, A-300 treatments stimulated microbial movement significantly, as was most evident in the stem elongation and heading stages, indicating that A-300 treatments were more beneficial for microbial movement than CTs or A-200 treatments.

\section{Discussion}

\section{Influence of hydrophilic polymers on soil water and wheat growth}

The results indicated that adding superabsorbent polymers could improve the soil WC and enable the soil to retain more water. 


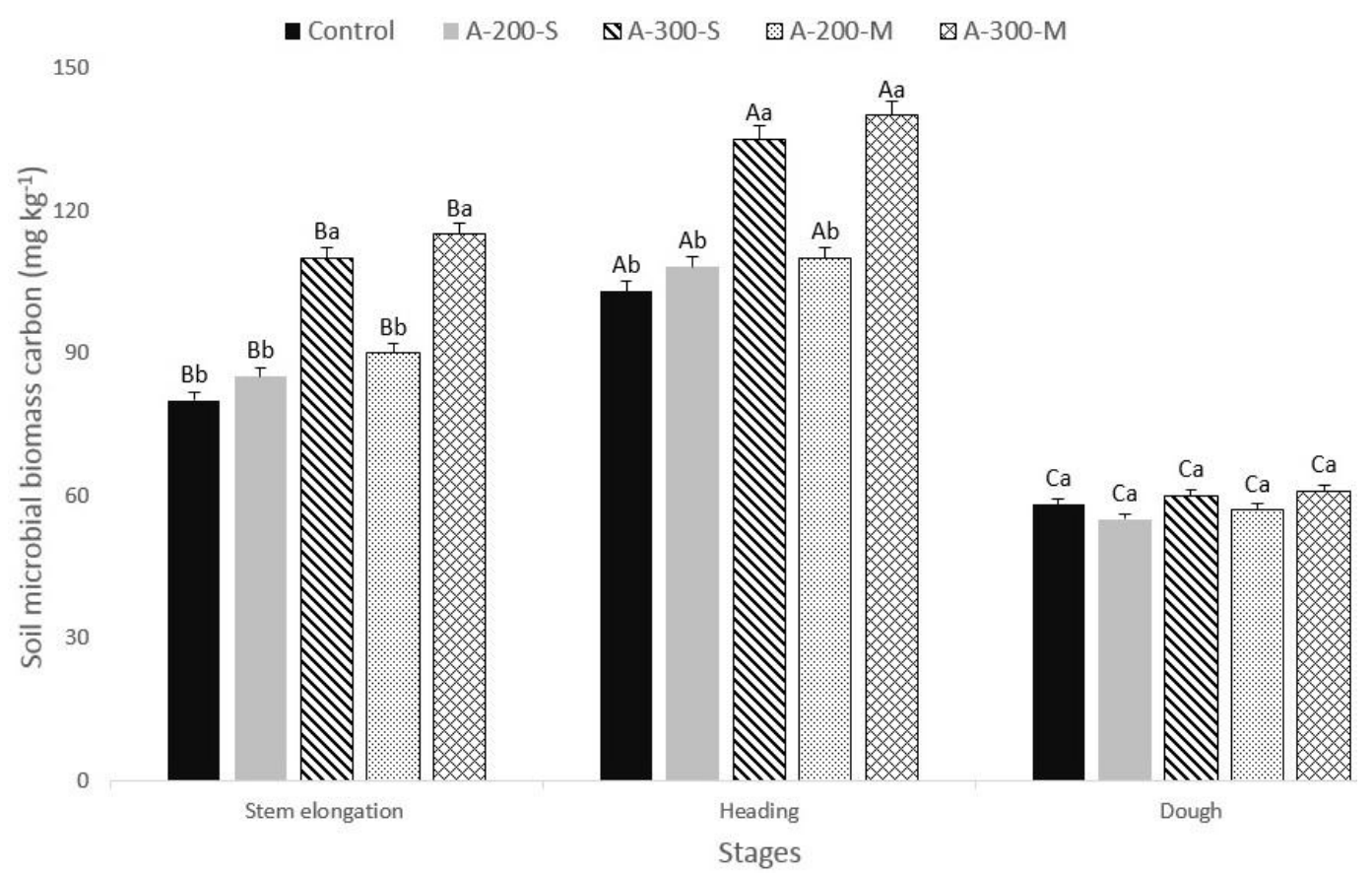

Figure 8. Soil microbial biomass carbon $(M B C)$ in varied stages and under varied hydrophilic polymer treatments. Different capital letters indicate significant differences between stages for the same SAP treatment $(P<0.05)$. Varied lowercase letters indicate significant differences between hydrophilic polymer treatments in the same wheat growth stage $(P<0.05)$. Bars show the standard errors

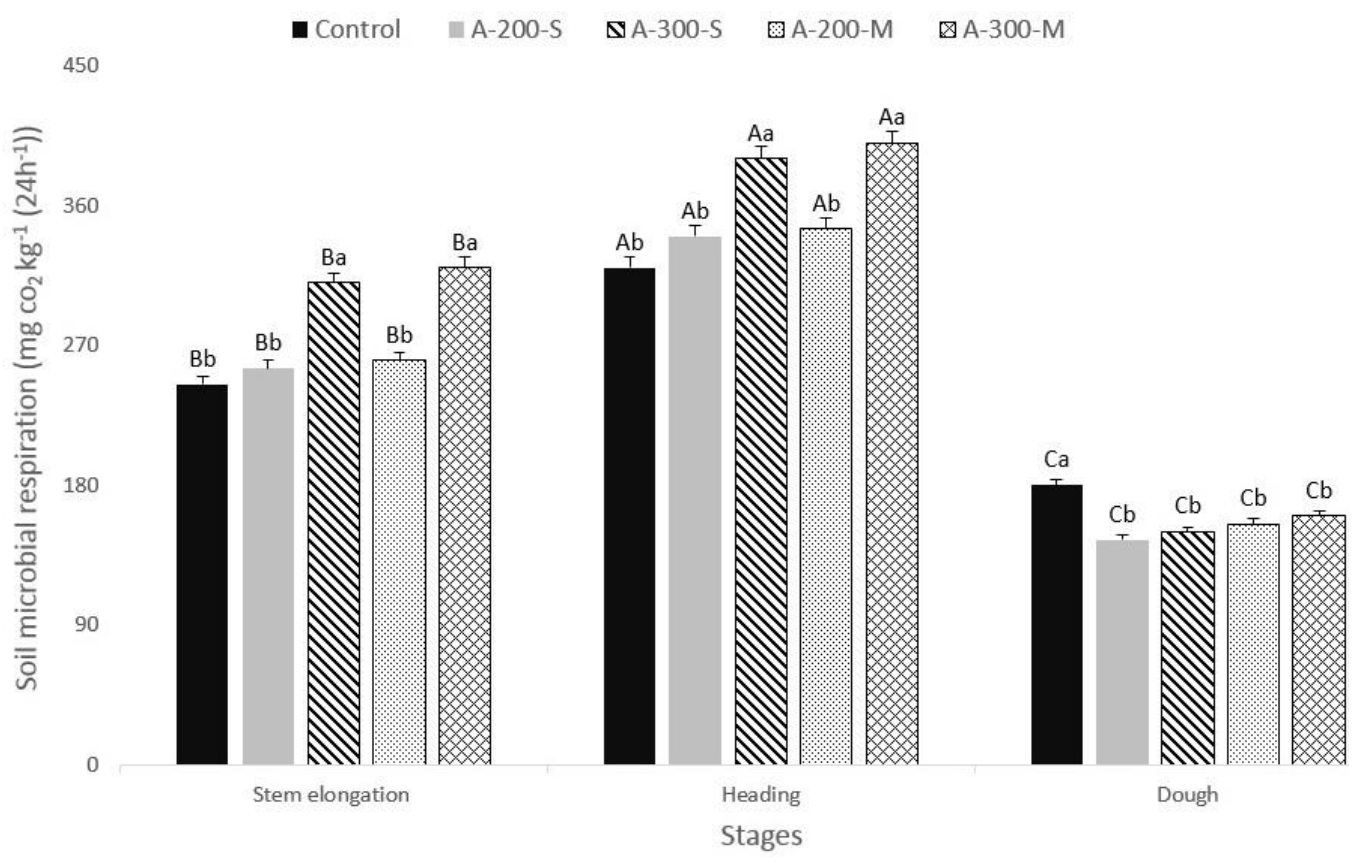

Figure 9. Soil microbial respiration (SMR) in varied stages and under varied hydrophilic polymer treatments. Different capital letters indicate significant differences between stages for the same SAP treatment $(P<0.05)$. Varied lowercase letters indicate significant differences between hydrophilic polymer treatments in the same wheat growth stage $(P<0.05)$. Bars show the standard errors 
Furthermore, superabsorbent polymers greatly influenced SHM; SHM was fixed by soil particles and might not be applied by wheat plants. The fact that hydrophilic polymers enhanced SWC but not the soil-available water content suggested that the benefits of hydrophilic polymers to wheat plant growth could be limited. This fact agreed with the finding that there were nearly no significant differences in grain dry weight (except A300-M treatment) or Chamran variety shoot length between all treatments. However, this finding differed from those of former studies with varied conditions, indicating that hydrophilic polymers could amend crop growth significantly (Yazdani et al., 2007; Islam et al., 2011).

\section{Influence of hydrophilic polymers on SWSA}

In the stem elongation stage, hydrophilic polymer treatment had no influence on large or small aggregates. However, in the heading and dough stages, A-200 and A-300 treatments raised more large aggregates related to CTs. Ajwa and Trout (2006) reported that hydrophilic polymers could be firmly adsorbed onto the soil particle surface, thereby stopping dispersion. However, the first sampling was conducted only 5 days after the use of hydrophilic polymers, and therefore, there could have been insufficient time for the hydrophilic polymer to connect perfectly with the soil particle surface. In the heading and dough stages, some part of the superabsorbent polymers would have gently infiltrated the aggregates pores ( $\mathrm{Lu}$ and $\mathrm{Wu}, 2003$ ) and protected or enhanced soil aggregation and pore continuation (Li et al., 2014; Ajwa and Trout, 2006; Keren and Ben-Hur, 1997).

\section{Influence of hydrophilic polymers on bacterial plenty}

The RG can present taxonomic information about the compound of bacterial colonies (Satoshi et al., 2009). RGs obtained under natural conditions have recently been used to gain insights into and understand the purposes of soil-borne microbial variations (Tiedje et al., 1999; Torsvik and Ovreas, 2002; Rodriguez-Valera, 2004; Schloss and Handelsman, 2004; Li et al., 2014). The addition of hydrophilic polymers significantly enhanced bacterial plenty from the first to the second phases of Chamran variety growth, indicating that bacterial growth had been increased. Furthermore, more RG copies were identified in the heading phase than in the other phases. This result indicates that bacterial reproduction increased upon adding hydrophilic polymers under natural conditions, particularly in the heading stage. Substrates achieved from plant, both those that were actively seeped and those that were inactively scattered, could provide most of the energy and food for soil-borne microbial colonies (Marschner et al., 2004; Li et al., 2014). Therefore, when the plants were growing quickly, they might produce more substrates, resulting in the levels of soil microbic movement being the greatest in the heading stage.

\section{Influence of hydrophilic polymers on soil microbial movements}

A significant enhancement in SMR and MBC was seen in the A-300 treatments (A300-M and A-300-S) in the stem elongation and heading stages (Figs. 8 and 9), especially in the heading stage. A-300-M had a stronger influence on MBC than A-300$\mathrm{S}$. High microbial movement and biomass often result in high nutrient access (Tu et al., 2003; Zaman et al., 1999) and may, in turn, result in high plant production (Tu et al., 2006; Li et al., 2014); this could explain the greater wheat yield obtained by the A-300- 
$M$ treatment compared to the other treatments. The significant reduction in SMR and MBC in the dough phase could be caused by the variations in colony size and construction that could result from variations in the input of metabolizable DOC from plant (Gomez et al., 2006) and soil residues arising from plant growth effects (Patra et al., 2006; Li et al., 2014). In this phase, hydrophilic polymers might have been decomposed incompletely or completely, resulting in lower amounts of SMR and MBC. This influence was most evident in the A-300 treatments, which significantly stimulated the microbial movements in the heading stage, thereby expediting the disintegration of soil organic matter. Therefore, the SMR decreased more clearly in the dough phase compared with that in the CT because the microorganisms did not have enough substrates available. The result indicates that this decrease in SMR was not related to the opposite influence of SAPs. These findings show that the use of SAPs did not reveal any opposite influences on wheat plant growth and the physical or microbial characteristics of soil. Soil is a complicated ecosystem that is influenced by numerous factors, making it difficult to evaluate environmental influences methodically and extensively when chemical additives are applied to the soil. Nonetheless, it is crucial to find an estimation frame and make suitable adaptations to it over time.

\section{Conclusions}

The results indicate that the use of hydrophilic polymers could amend the physical characteristics of soil and may help in managing water loss. At a density of $180 \mathrm{~kg} \mathrm{ha}^{-1}$, hydrophilic polymers greatly increased the uptake of water and the presence of WSA. SAPs did not have obvious opposite effects on the soil microbial colony and might even increase it. The influences of hydrophilic polymers also depended on the processes used in the field, as only the mass application of A-300 improved the yield. No direct relations were found between the SWC and the plant characteristics. Finally, it is recommended to use other types of hydrophilic polymers on the other soil types for managing water loss. Besides, it is recommended to use other plants and other growth stages for soil sampling.

\section{REFERENCES}

[1] Ajwa, H. A., Trout, T. J. (2006): Polyacrylamide and water quality effects on infiltration in sandy loam soils. - Soil Sci. Soc. Am. J. 70: 643-650.

[2] Bouwer, H. (2002): Integrated water management for the 21st century: Problems and solutions. - J. Irrig. Drain. Eng. 128: 193-202.

[3] Chen, C., Condron, L. M., Davis, M., Sherlock, R. R. (2000): Effects of afforestation on phosphorus dynamics and biological properties in a New Zealand grassland soil. - Plant Soil 220: 151-163.

[4] Elliot, E. T. (1986): Aggregate structure and carbon, nitrogen, and phosphorus in native and cultivated soils. - Soil Sci. Soc. Am. J. 50: 627-633.

[5] Gupta, S. C., Larson, W. E. (1979): Estimating soil water retention characteristics from particle size distribution, organic matter percent and bulk density. - Water Resour. Res. 15: 1633-1635.

[6] Gomez, E., Ferreras, L., Toresani, S. (2006): Soil bacterial functional diversity as influenced by organic amendment application. - Bioresour. Technol. 97: 1484-1489.

[7] He, J. Z., Shen, J. P., Zhang, L. M., Zhu, Y. G., Zheng, Y. M., Xu, M. G., Di, H. J. (2007): Quantitative analyses of the abundance and composition of ammonia-oxidizing 
bacteria and ammonia-oxidizing archaea of a Chinese upland red soil under long-term fertilization practices. - Environ. Microbiol. 9: 2364-2374.

[8] Islam, M. R., Hu, Y., Mao, S., Jia, P., Eneji, A. E., Xue, X. (2011): Effects of watersaving superabsorbent polymer on antioxidant enzyme activities and lipid peroxidation in corn (Zeamays L.) under drought stress. - J. Sci. Food Agric. 91: 813-819.

[9] Jonasson, S., Michelsen, A., Schmidt, I. K., Nielsen, E. V. (1996): Microbial biomass C $\mathrm{N}$ and $\mathrm{P}$ in two arctic soils and responses to addition of NPK fertilizer and sugar: implications for plant nutrient uptake. - Oecologia 106: 507-515.

[10] Keren, R., Ben-Hur, M. (1997): Polymer effects on water infiltration and soil aggregation. - Soil Sci. Soc. Am. J. 61: 565-570.

[11] Khadem, S. A., Galavi, M., Ramrodi, M., Mousavi, S. R., Rousta, M. J., RezvaniMoghaddam, P. (2010): Effect of animal manure and superabsorbent polymer on corn leaf relative water content, cell membrane stability and leaf chlorophyll content under dry condition. - Australian Journal of Crop Science 4: 242-247.

[12] Khodadadi Dehkordi, D. (2017): Effect of superabsorbent polymer on salt and drought resistance of Eucalyptus globulus. - Applied Ecology and Environmental Research 15: $1791-1802$.

[13] Li, X., He, J., Hughes, J., Liu, Y., Zheng, Y. (2014): Effects of super-absorbent polymers on a soil-wheat (Triticum aestivum L.) system in the field. - Applied Soil Ecology 73: $58-63$.

[14] Lu, J. H., Wu, L. S. (2003): Polyacrylamide distribution in columns of organic matter removed soils following surface application. - J. Environ. Qual. 32: 674-680.

[15] Marschner, P., Crowley, D., Yang, C. H. (2004): Development of specific rhizosphere bacterial communities in relation to plant species, nutrition and soil type. - Plant Soil 261: 199-208.

[16] Orikiriza, L. J. B., Agaba, H., Tweheyo, M., Eilu, G., Kabasa, J. D., Huttermann, A. (2009): Amending soils with hydrogels increases the biomass of nine tree species under non-water stress conditions. - Clean Soil Air Water 37: 615-620.

[17] Patra, A. K., Abbadie, L., Clays-Josserand, A., Degrange, V., Grayston, S. J. (2006): Effects of management regime and plant species on the enzyme activity and genetic structure of $\mathrm{N}$-fixing, denitrifying and nitrifying bacterial communities in grass-land soils. - Environ. Microbiol. 8: 1005-1016.

[18] Rahab Resin Co. (2016): Rahab Resin Company. http://www.bizearch.com/company/Rahab_Resin_Co_280864.htm. Access date: 9 October 2016.

[19] Rinnan, R., Michelsen, A., Jonasson, S. (2008): Effects of litter addition and warming on soil carbon, nutrient pools and microbial communities in a subarctic heath ecosystem. Appl. Soil Ecol. 39: 271-281.

[20] Rodriguez-Valera, F. (2004): Environmental genomics, the big picture? - FEMS Microbiol. Lett. 231: 153-158.

[21] Satoshi, I., Michihiro, Y., Mami, K. (2009): Microbial populations responsive to denitrification-inducing conditions in rice paddy soil, as revealed by comparative $16 \mathrm{~S}$ rRNA gene analysis. - Appl. Environ. Microbiol. 75: 7070-7078.

[22] Schloss, P. D., Handelsman, J. (2004): Status of the microbial census. - Microbiol. Mol. Biol. Rev. 68: 686-691.

[23] Seyed Doraji, S., Golchin, A., Ahmadi, S. (2010): The effects of different levels of a Superabsorbent polymer and soil salinity on water holding capacity with three textures of sandy, loamy and clay. - Journal of Water and Soil 24: 306-316 (in Persian).

[24] Tiedje, J. M., Asuming-Brempong, S., Nusslein, K., Marsh, T. L., Flynn, S. J. (1999): Opening the black box of soil microbial diversity. - Appl. Soil Ecol. 13: 109-122.

[25] Torsvik, V., Ovreas, L. (2002): Microbial diversity and function in soil: from genes to ecosystems. - Curr. Opin. Microbiol. 5: 240-245. 
[26] Tu, C., Koenning, S. R., Hu, S. (2003): Root-parasitic nematodes enhance soil microbial activities and nitrogen mineralization. - Microbial. Ecol. 46: 134-144.

[27] Tu, C., Koenning, S. R., Hu, S. (2006): Soil microbial biomass and activity in organic tomato farming systems: effects of organic inputs and straw mulching. - Soil Biol. Biochem. 38: 247-255.

[28] Vance, E. D., Brookes, P. C., Jenkinson, D. S. (1987): An extraction method for measuring microbial biomass C. - Soil Biol. Biochem. 22: 703-707.

[29] Yang, L., Yang, Y., Chen, Z., Guo, C., Li, S. (2014): Influence of super absorbent polymer on soil water retention, seed germination and plant survivals for rocky slopes eco-engineering. - Ecological Engineering 62: 27-32.

[30] Yadollahi, A., Teimoori, N., Abdoosi, V., Sarikhani-Khorami, S. (2012): Impact evaluation of Superabsorbent and organic matters in retention of water and establishment of Almond gardens in rainfed conditions. - Journal of Water Research in Agriculture 26: 95-106 (in Persian).

[31] Yazdani, F., Allahdadi, I., Akbari, G. A. (2007): Impact of superabsorbent polymer on yield and growth analysis of soybean (Glycine max L.) under drought stress condition. Pak. J. Biol. Sci. 10: 4190-4196.

[32] Zaman, M., Di, H. J., Cameron, K. C. (1999): A field study of gross rates of N mineralization and nitrification and their relationships to microbial biomass and enzyme activities in soils treated with dairy effluent and ammonium fertilizer. - Soil Use Manage. 15: $188-194$.

[33] Zhang, X. C., Miller, W. P. (1996): Polyacrylamide effect on infiltration and erosion in furrows. - Soil Sci. Soc. Am. J. 60: 866-872. 